\title{
Biologics in the management of psoriasis
}

REVIEW

This article was published in the following Dove Press journal:

Clinical, Cosmetic and Investigational Dermatology

22 July 2009

Number of times this article has been viewed

Jennifer D Bahner'

Lauren $\mathrm{Y} \mathrm{Cao}^{2}$

Neil J Korman'

'Department of Dermatology, University Hospitals Case Medical

Center, Cleveland, Ohio, USA; ${ }^{2}$ Case

Western Reserve University School

of Medicine, Cleveland, Ohio, USA
Correspondence: Neil J Korman,

I I 100 Euclid Avenue, Cleveland,

Ohio 44I06, USA

$\mathrm{Tel}+\mathrm{I}(2 \mathrm{I}$ ) 844-8200

$\mathrm{Fax}+\mathrm{I}(216) 844-8993$

Email neil.korman@uhhospitals.org
Abstract: Psoriasis is a chronic inflammatory systemic disease for which there exist topical, ultraviolet, systemic, and biologic treatments. Biologic agents selectively interfere with the immune mechanisms responsible for psoriasis. Etanercept, infliximab, and adalimumab target tumor necrosis factor-alpha and have demonstrated efficacy in the treatment of psoriasis and psoriatic arthritis. Alefacept and efalizumab target $\mathrm{T}$ lymphocytes, are effective in the treatment of psoriasis, but are not approved for psoriatic arthritis. Finally, ustekinumab and ABT-874 target interleukin-12 and interleukin-23, and they have demonstrated efficacy in the treatment of psoriasis. The objective of this review is to present efficacy and safety data from randomized controlled trials of the biologic agents in the treatment of psoriasis.

Keywords: biologics, psoriasis, tumor necrosis factor, interleukin-12/23

\section{Introduction}

Psoriasis is a chronic inflammatory systemic disease which affects approximately $1 \%$ to $3 \%$ of the world's population, ${ }^{1}$ and it is the most prevalent immune-mediated skin disease in adults. ${ }^{2}$ Psoriasis can have significant physical, psychological, and economic impacts on patients, leading to reduced quality of life, ${ }^{3-9}$ especially for patients with severe disease. ${ }^{10}$ Approximately $25 \%$ of patients have moderate to severe psoriasis. ${ }^{11}$ Additionally, individuals with psoriasis have increased incidence of other chronic disorders including metabolic syndrome, coronary artery disease, diabetes mellitus, hypertension, fatigue, and depression. ${ }^{12-15}$

Depending on the study, between $5 \%$ and $42 \%$ of psoriasis patients develop psoriatic arthritis (PsA). ${ }^{16} \mathrm{PsA}$, once considered a benign arthropathy, is in fact a severe disease. A growing body of literature suggests that PsA is often progressive and is associated with accelerated mortality, substantial morbidity, and impaired quality of life. ${ }^{17,18}$

Conventional systemic treatments for moderate to severe psoriasis, including phototherapy with ultraviolet B (UVB), photochemotherapy with psoralens and ultraviolet A (PUVA), methotrexate, cyclosporine, and acitretin are limited by well-known and characteristic side effects, incomplete effectiveness in some patients, and demanding treatment schedules which result in decreased patient compliance. ${ }^{19}$ Likewise, treatment of moderate to severe PsA with conventional disease modifying anti-rheumatic drugs (DMARDs) has not uniformly been shown to have efficacy, especially in treating cutaneous symptoms. ${ }^{20-23} \mathrm{~A}$ meta-analysis of published randomized controlled trials (RCTs) on DMARDs found that only parenteral high-dose methotrexate 
and sulfasalazine had efficacy in $\mathrm{PsA},{ }^{24}$ while another trial showed moderate efficacy of leflunomide in PsA. ${ }^{25}$

The biologic agents have greatly increased the treatment choices for patients with moderate to severe psoriasis as well as those with moderate to severe PsA. The biologics used in treating psoriasis and PsA may be categorized as those inhibiting tumor necrosis factor-alpha (TNF- $\alpha$ ) (ie, etanercept, infliximab, adalimumab), those inhibiting $\mathrm{T}$ cells (ie, efalizumab, alefacept), and those that block interleukin-12 and interleukin-23 (IL-12/23) (ie, ustekinumab, ABT-874).

Biologic agents should be used with caution, as robust, long-term data in psoriasis are not yet available. Physicians must continue to monitor for long-term adverse events such as chronic immunosuppression, which may lead to increased risks of infection and malignancy. ${ }^{2}$ It is also important to consider the high cost of biologic agents and the patient selection criteria used thus far in clinical trials and other studies. ${ }^{26}$ Before initiating therapy with a biologic agent, patients must be screened (Table 1) to ensure that they are appropriate candidates and to minimize adverse events.

\section{Role of TNF- $\alpha$ in psoriasis}

TNF- $\alpha$ is a pro-inflammatory cytokine that is a member of a growing family of cytokines known as the TNF superfamily. ${ }^{27}$ Binding of TNF- $\alpha$ to its receptors induces downstream signaling that ultimately augments the expression of pro-inflammatory genes. ${ }^{27,28}$ TNF- $\alpha$ has numerous effects important in the pathogenesis of psoriasis and PsA. TNF- $\alpha$ production and activity are elevated in lesional psoriatic skin compared with non-lesional psoriatic skin and non-psoriatic skin. ${ }^{29-32}$ TNF- $\alpha$ production and activity have also been shown to

Table I Recommended actions before initiating biologic therapy for psoriasis and psoriatic arthritis

\begin{tabular}{l} 
Age appropriate history \\
Physical examination \\
Current medication list \\
Baseline laboratory tests \\
Liver function tests \\
Complete blood cell count, including platelet count \\
Hepatitis panel \\
Tuberculosis skin test (PPD) \\
Urine pregnancy test \\
Ensure up-to-date status in standard vaccinations, including \\
pneumococcal, hepatitis A and B, influenza, tetanus-diphtheria \\
\hline
\end{tabular}

Abbreviation: PPD, purified protein derivative. be higher in non-lesional psoriatic skin than non-psoriatic skin. ${ }^{30}$ Furthermore, serum TNF- $\alpha$ levels are higher in individuals with psoriasis than those without it, ${ }^{33,34}$ and synovial fluid TNF- $\alpha$ levels are higher in individuals with PsA. ${ }^{35-37}$ Lesional and serum TNF- $\alpha$ levels correlate with psoriasis disease severity as measured by the psoriasis area and severity index $(\mathrm{PASI})^{31}$ score. With effective therapy and clinical improvement, psoriasis patients exhibit decreased levels of lesional skin and serum TNF- $\alpha . .^{33-39}$

\section{Etanercept}

Etanercept is a dimeric fusion protein consisting of the extracellular ligand-binding domain of the human TNF- $\alpha$ receptor fused to the constant fragment (Fc domain) of human immunoglobulin G1 (IgG1). ${ }^{27}$ It is currently approved by the Food and Drug Administration (FDA) for the treatment of moderate to severe psoriasis, moderate to severe PsA, adult rheumatoid arthritis, juvenile rheumatoid arthritis in patients as young as 4 years old, and ankylosing spondylitis. Etanercept is administered via subcutaneous injection (SC), and the FDA-approved regimen for psoriasis is $50 \mathrm{mg}$ twice weekly (BIW) for 12 weeks followed by $50 \mathrm{mg}$ weekly (QW) thereafter. Although numerous clinical trials have been conducted with etanercept $25 \mathrm{mg}$ BIW, ${ }^{40-42}$ recent studies have shown etanercept $50 \mathrm{mg}$ QW to have comparable efficacy, safety, and pharmacokinetic profiles, with improved convenience. ${ }^{43,44}$ In a study in which subjects were treated with etanercept $50 \mathrm{mg}$ BIW for 12 weeks followed by 12 weeks of etanercept $25 \mathrm{mg}$ BIW, 77\% of subjects maintained response despite dose reduction. ${ }^{45}$ For PsA, the dosing regimen is $25 \mathrm{mg}$ BIW or $50 \mathrm{mg}$ QW, and etanercept is often used in combination with methotrexate.

Improvement in PsA may be noticeable as soon as 2 weeks after starting treatment, while skin improvement is usually slower. ${ }^{46}$ In one trial, improvements in psoriasis were observed for up to 96 weeks with continuous etanercept therapy, with a peak in response after 48 weeks of treatment. ${ }^{47}$ Nevertheless, etanercept loses efficacy over time in some patients, possibly due to the development of antibodies. In one open-label trial, clinical response was maintained in a higher proportion of psoriasis patients treated with continuous rather than as-needed etanercept therapy; ${ }^{48}$ however, the trial only examined one round of re-treatment, and patients in the continuous group received more total medication. Patients do not typically experience rebound psoriasis after etanercept is discontinued. ${ }^{45,48,49}$

In contrast to infliximab and adalimumab, etanercept is able to bind to both TNF- $\alpha$ and lymphotoxin- $\alpha$ 
(TNF- $\beta$ ), although the clinical significance of its binding to lymphotoxin- $\alpha$ is unknown. ${ }^{50}$ Since etanercept has two binding sites for TNF- $\alpha$, it binds TNF- $\alpha$ with greater affinity than do natural monomeric receptors. ${ }^{51}$ Consequently, etanercept competitively inhibits membrane-associated and soluble TNF- $\alpha$ from binding its natural receptors and inducing downstream signal transduction, resulting in a decrease in inflammatory activity.

Although excessive TNF- $\alpha$ contributes to the pathogenesis of psoriasis and PsA, a physiological level of TNF- $\alpha$ is important in protecting the body against opportunistic infection and malignancy. Hence, TNF- $\alpha$ antagonists should be administered in doses within the therapeutic window, reducing systemic and local TNF- $\alpha$ levels to within physiologically normal ranges but not so low as to lead to adverse events. ${ }^{52,53}$ Unlike infliximab and similar to adalimumab, the combination of slow absorption rate following SC administration, slow elimination rate, and appropriate dosing frequency give etanercept a smooth and uniform concentration-time profile, minimizing the occurrence of overexposure and resultant adverse events, as well as underexposure and consequent symptom recurrence. ${ }^{52,53}$

Obesity, defined as body mass index (BMI) greater than or equal to $30 \mathrm{~kg} / \mathrm{m}^{2}$, is on the rise. ${ }^{54}$ Recent studies have demonstrated higher prevalence of obesity and overweight in individuals with psoriasis than those without psoriasis. ${ }^{55-58}$ Obese patients also tend to have more severe psoriasis than those with psoriasis who are not obese. Additionally, some conditions associated with obesity, such as nonalcoholic fatty liver disease, are relative contraindications to systemic treatments for psoriasis. ${ }^{59}$

Etanercept is administered via a fixed-dose regimen that is not dependent on the patient's weight. Gordon et $\mathrm{al}^{49}$ performed subgroup analyses of data pooled from three large clinical trials. Among all subjects receiving etanercept, a 75\% or greater reduction in the psoriasis area and severity index score (PASI 75 response) was achieved by $47 \%$ of subjects weighing less than and $33 \%$ of those weighing greater than the median weight $(89.36 \mathrm{~kg})$. Strober et $\mathrm{al}^{60}$ conducted a subgroup analysis of a phase III trial where 618 patients were randomized to receive etanercept $50 \mathrm{mg}$ SC BIW or placebo. "Superior response" was defined as PASI 90 response at 3 or more visits, and "sub-optimal response" was defined as failure to attain at least PASI 50 response at 3 or more visits. Superior response was achieved by $41 \%$ of normalweight subjects and $15 \%$ of extremely obese (BMI $\geq 40$ ) subjects. Sub-optimal response was reported in only $9 \%$ of normal-weight patients, compared to $27 \%$ of extremely obese patients. These results suggest that normal-weight patients have a greater response to etanercept than heavier patients and support the idea of using etanercept less frequently in the most overweight patients. Interestingly, recent reports suggest that treatment with the TNF- $\alpha$ inhibitors, but not with efalizumab or methotrexate, may lead to weight gain. ${ }^{62}$

There have been a number of clinical trials assessing the efficacy and safety of etanercept in treating psoriasis and PsA (Table 2) as well as demonstrating improvement in dermatology-related quality of life. ${ }^{61,63,64}$ Furthermore, etanercept is the only biologic agent that has data in pediatric and adolescent psoriasis patients, and it has demonstrated efficacy and safety in this patient population. ${ }^{65}$

The most common adverse events (AEs) with etanercept use are injection site reaction and infection. Other common AEs include fever, headache, mild allergic reaction, and pruritus. There exist rare reports of anaphylaxis, angioedema, exacerbation of or new-onset congestive heart failure (CHF), cytopenia, increased liver function tests (LFTs), leukocytoclastic vasculitis, lupus erythematosus syndrome, malignancy (eg, Hodgkin's lymphoma, cutaneous T-cell lymphoma (CTCL), nonmelanoma skin cancer [NMSC]), multiple sclerosis (MS) or other demyelinating disease, sepsis, severe infection (eg tuberculosis [TB]), and urticaria. ${ }^{41,42,49,50,66-69}$ The incidence of AEs, serious adverse events (SAEs), and infection occurring in clinical trials of etanercept is summarized in Table 2.

Contraindications for etanercept use include chronic, active, serious, and recurrent infection, active TB, latent TB in the absence of chemoprophylaxis, hepatitis B, MS and other demyelinating disease, a first-degree relative with MS, New York Heart Association (NYHA) class III or IV CHF, pregnancy or lactation, and hypersensitivity to etanercept or its ingredients. During treatment with etanercept, patients should avoid live and live-attenuated vaccines. Table 3 lists monitoring recommendations for all TNF- $\alpha$ inhibitors. Note that most safety information about TNF- $\alpha$ inhibitors is derived from studies of their use in rheumatoid arthritis and inflammatory bowel disease. ${ }^{66}$

\section{Infliximab}

Infliximab is a chimeric TNF- $\alpha$ monoclonal antibody consisting of the human constant and mouse variable regions of the $\mathrm{IgG}$ antibody. ${ }^{70}$ It is currently FDA-approved for treating severe psoriasis, moderate to severe PsA, adult rheumatoid arthritis, ankylosing spondylitis, adult and pediatric Crohn's disease, and ulcerative colitis. Infliximab is administered via intravenous infusions (IV) which span 


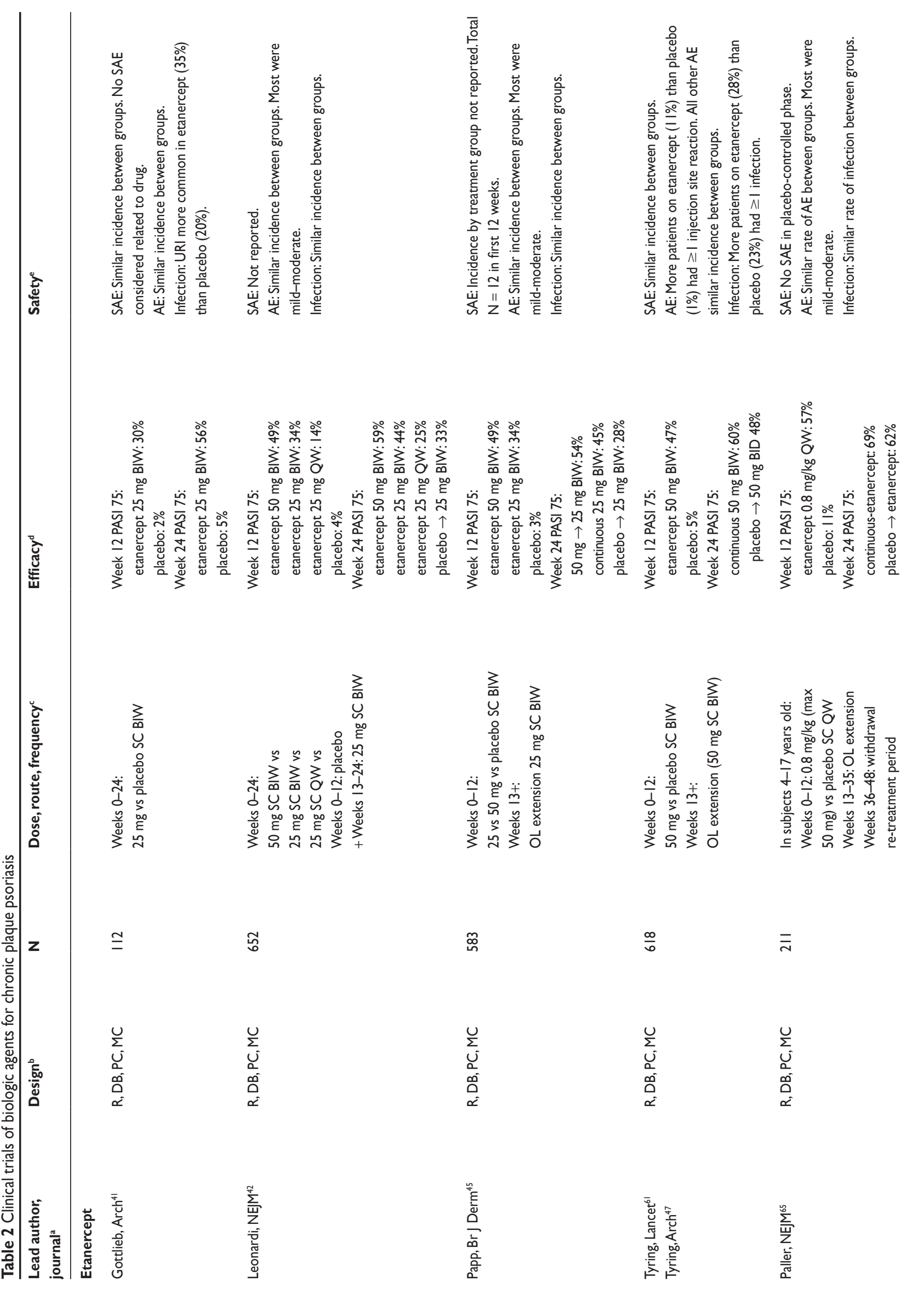



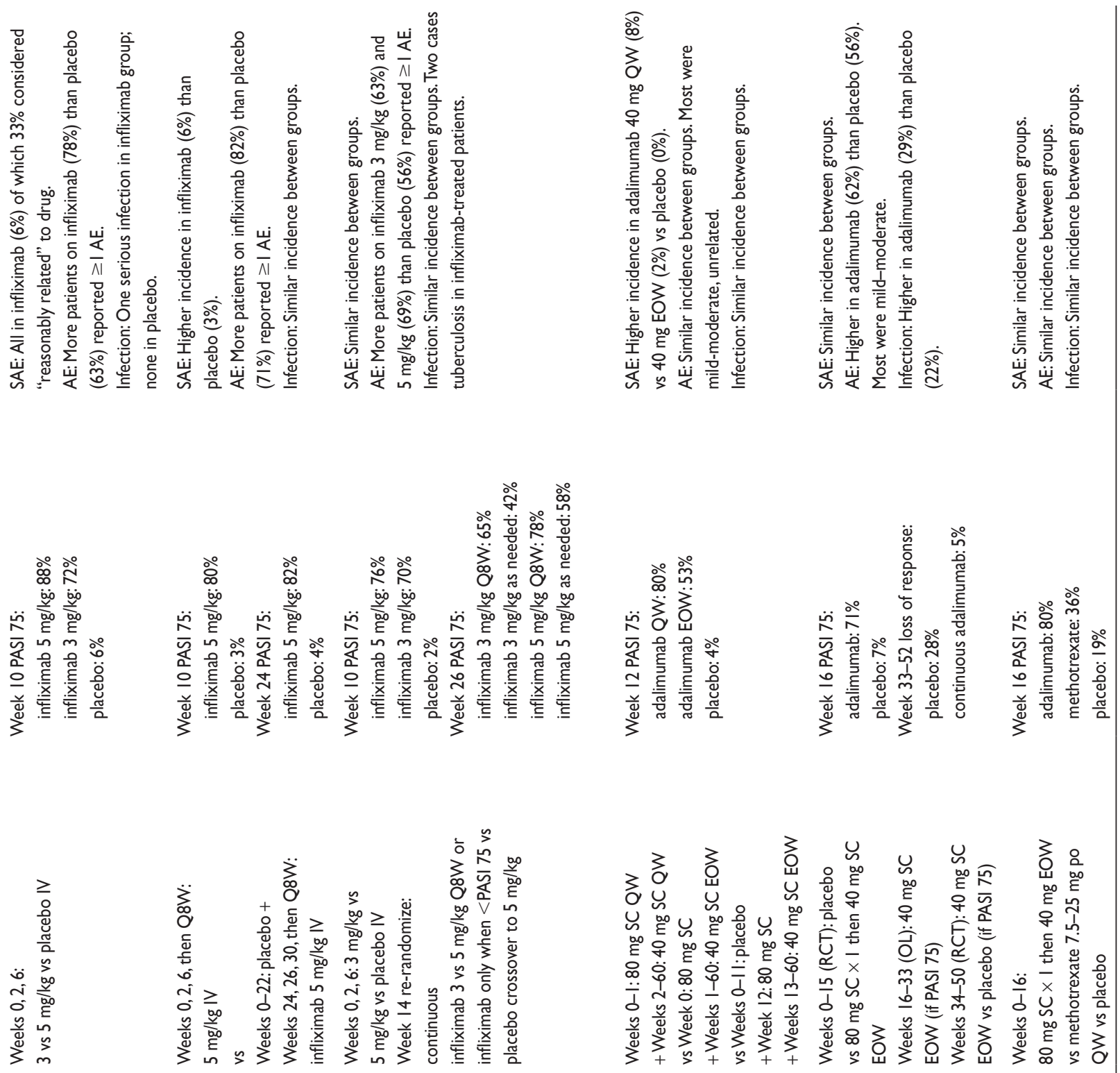

d

$\stackrel{\infty}{m}$

$\stackrel{\infty}{\infty}$

主

$\stackrel{\simeq}{\simeq}$

$\overline{4}$

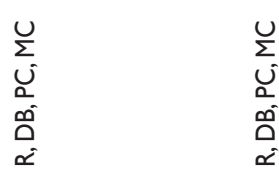

$u$
$\sum$
$u$
0
0
$\alpha$
$\alpha$

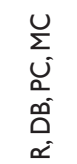

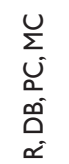

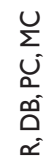

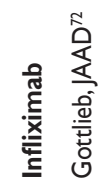

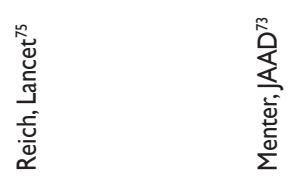

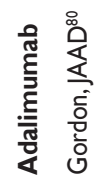

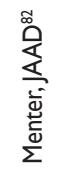

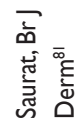




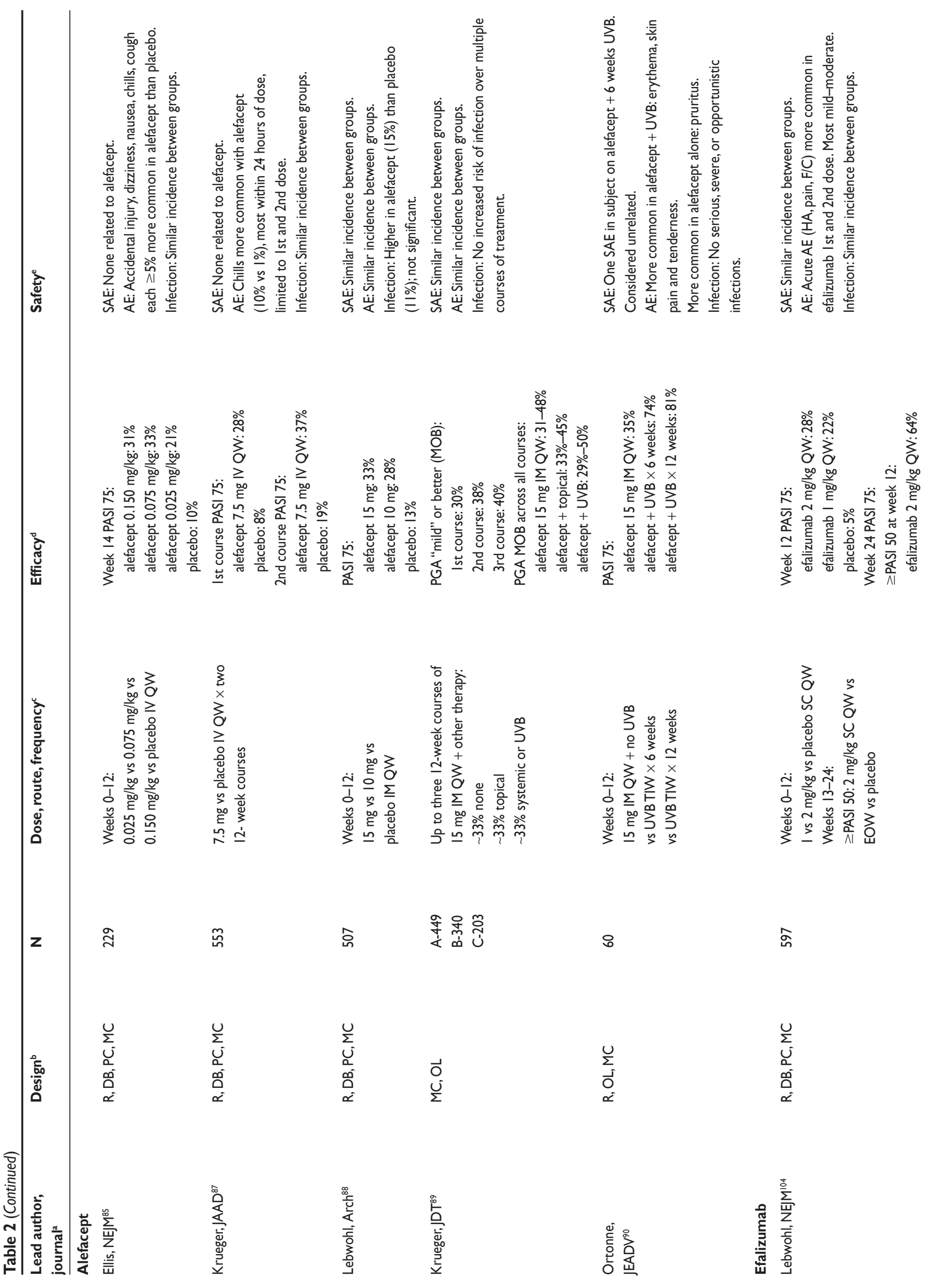



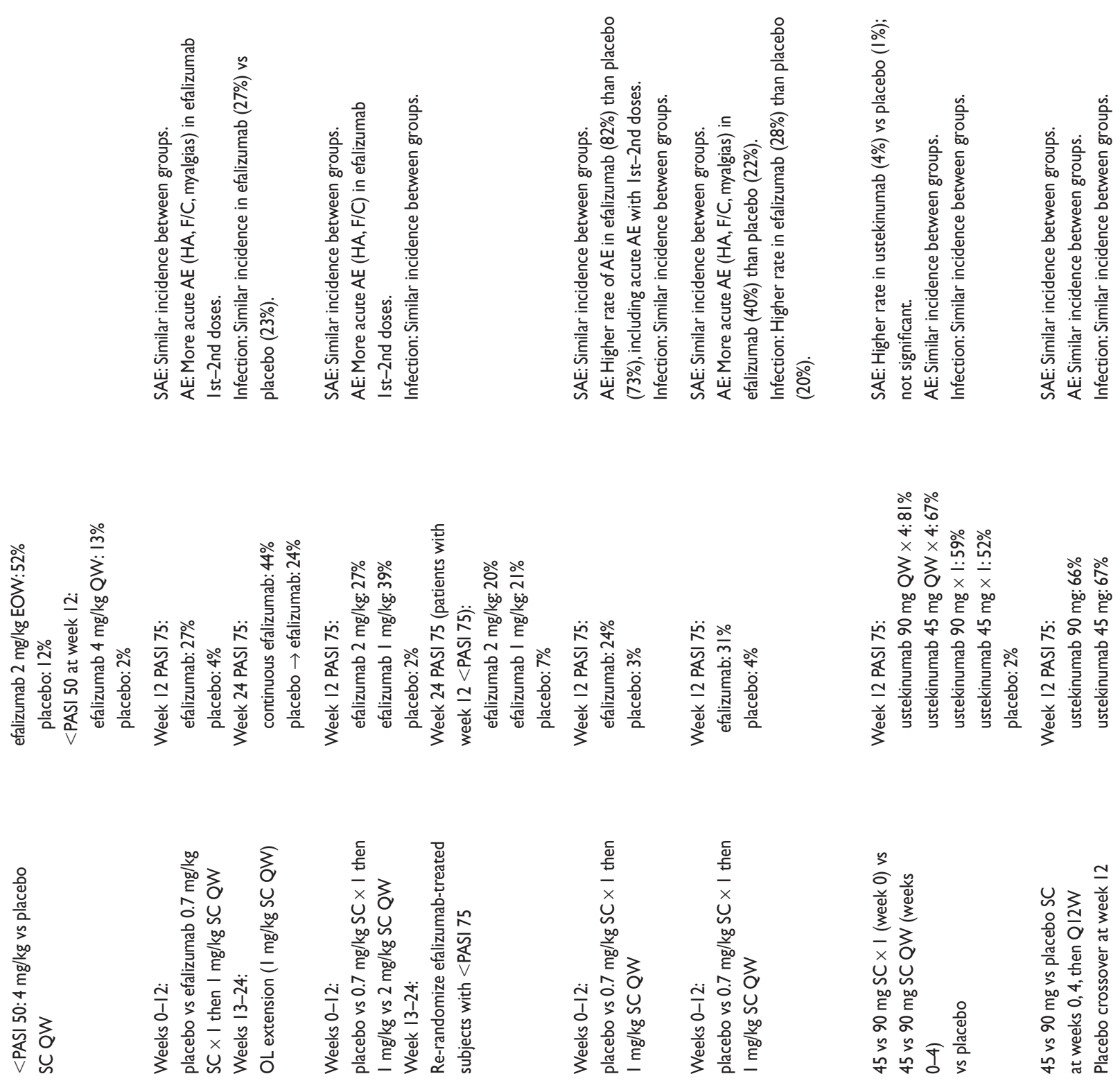

品 ํㅡํ

$\stackrel{\infty}{\alpha}$

ळ

న

ฉ్

$\stackrel{\circ}{2}$

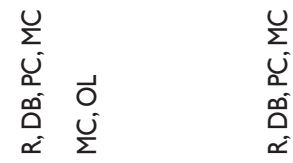

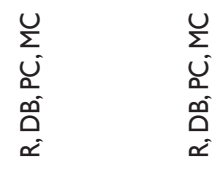

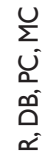

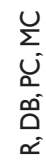

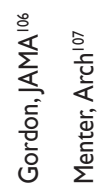

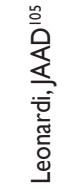

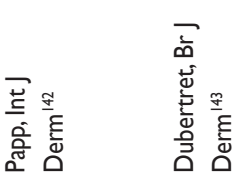

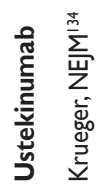




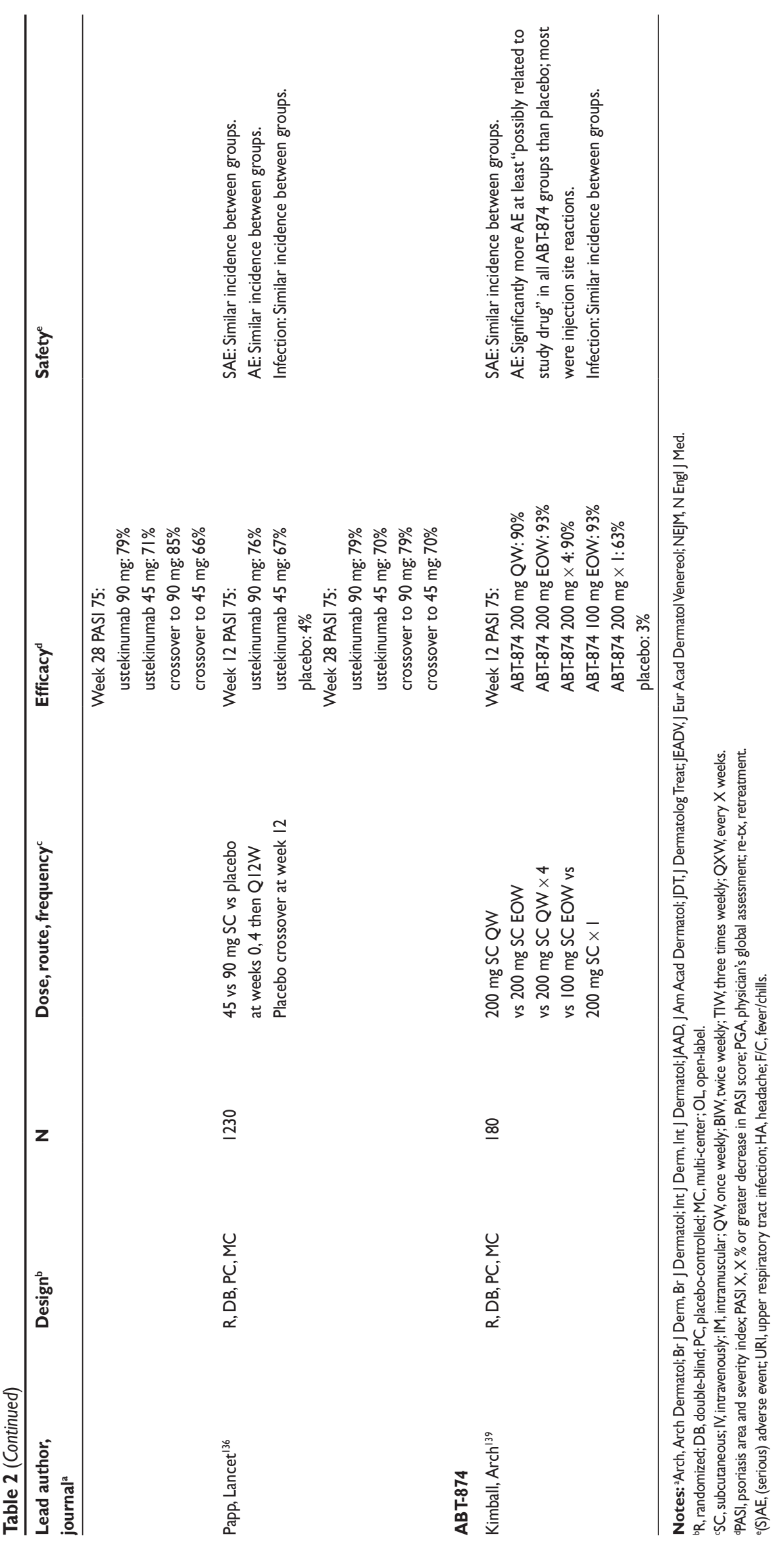


Table 3 Recommended monitoring during treatment with tumor necrosis factor-alpha inhibitors

In all patients:

Periodic history and physical examination

Periodic liver function tests

Periodic complete blood count

Yearly tuberculosis skin test (PPD)

In patients with hepatitis $\mathrm{C}$ :

Periodic monitoring of liver function tests

Periodic hepatitis $C$ viral load

Abbreviation: PPD, purified protein derivative

2 to 3 hours per session. For psoriasis and PsA, infliximab is given at a dose of $5 \mathrm{mg} / \mathrm{kg}$ at weeks 0,2 , and 6 , followed by maintenance infusions every 6 to 8 weeks.

Clinical response to infliximab can be quite rapid, with significantly higher PASI improvements than placebo as early as 2 weeks after starting treatment. ${ }^{11,71-73}$ In one metaanalysis, Brimhall et al noted that the relative risk (RR) of PASI 75 achievement was higher with infliximab than with any of the other biologic agents. ${ }^{69}$ Another meta-analysis found infliximab to have superior efficacy for treating moderate to severe psoriasis than adalimumab, etanercept, efalizumab, alefacept, methotrexate, cyclosporine, acitretin, and fumaric acid ester. ${ }^{74}$

Loss of efficacy may occur over time with infliximab treatment, especially in patients who do not achieve stable infliximab serum concentrations. ${ }^{75}$ This loss of efficacy may be due to the development of anti-chimeric antibodies. Clinical responses are better and patients are less likely to develop antibodies against infliximab if they are treated continuously rather than as-needed. ${ }^{72}$ Low-dose methotrexate or other immunosuppressive agents are sometimes prescribed concurrently with infliximab to help maintain infliximab's efficacy over time; this may be due to a reduction in the formation of antibodies. ${ }^{76}$

Infliximab binds to and neutralizes soluble and membrane-bound TNF- $\alpha$ with high specificity, affinity, and avidity, thereby decreasing inflammation. ${ }^{77}$ It is even able to inactivate TNF- $\alpha$ bound to TNF receptors. ${ }^{11}$ The infliximab/TNF- $\alpha$ complex is much more stable than the etanercept/TNF- $\alpha$ complex. ${ }^{78}$

The IV administration of infliximab, along with its long elimination half-life, significant loading doses (630 to $2100 \mathrm{mg}$ administered within 6 weeks for a 70-kg patient), and relatively high maintenance doses (210 to $700 \mathrm{mg}$ for a 70 -kg patient) create concentration-time profiles with very high peaks and low troughs. ${ }^{52,53,71}$ Although this pharmacokinetic profile is not the most desirable one, the high efficacy rates of infliximab may balance these effects.

Unlike etanercept and adalimumab, infliximab dosing is weight-based. In a subgroup analysis of 1462 subjects in three RCTs of infliximab for moderate to severe psoriasis, Reich et al demonstrated infliximab's comparable efficacy in subjects of varying weights. ${ }^{79}$ Similar proportions of overweight (78\%), obese (74\%), and normal-weight (78\%) subjects achieved PASI 75 response.

A number of clinical trials have demonstrated the efficacy and safety of infliximab in treating psoriasis and PsA (Table 2). According to one meta-analysis, patients treated with infliximab had a higher rate of adverse events compared to those treated with placebo $(\mathrm{RR}=1.18, P<0.001){ }^{69}$ Infusion reactions are among the most common AEs, and they are more frequent in patients who have developed anti-chimeric antibodies, those using infliximab in an as-needed fashion, and those not being treated concurrently with methotrexate or cyclosporine. ${ }^{66,73}$ Infusion reactions present typically as fever, chills, headache, flushing, nausea, dyspnea, dysgeusia, pruritus, and urticaria; they present less frequently as chest pain, hypertension, hypotension, or anaphylaxis. These reactions can usually be managed by slowing the infusion rate or stopping treatment. ${ }^{66}$ Other common AEs include infection, increased LFTs, pruritus, and serum sickness. There exist rare reports of anaphylaxis, exacerbation of or new-onset CHF, cytopenia, hepatitis, interstitial pneumonitis or fibrosis, leukocytoclastic vasculitis, lupus erythematosus syndrome, malignancy (eg, Hodgkin's lymphoma, CTCL, NMSC, hepatosplenic T-cell lymphoma), MS or other demyelinating disease, optic neuritis, pancreatitis, seizure, sepsis, and severe infections. ${ }^{66,68,72,73,75}$

Contraindications for infliximab use include chronic, active, serious, and recurrent infection, active TB, latent TB in the absence of chemoprophylaxis, hepatitis B, MS and other demyelinating disease, a first-degree relative with MS, NYHA class III or IV CHF, pregnancy or lactation, and hypersensitivity to infliximab, murine proteins, or other ingredients. During treatment with infliximab, patients should avoid live and live-attenuated vaccines. Table 3 lists monitoring recommendations for all TNF- $\alpha$ inhibitors.

\section{Adalimumab}

Adalimumab is a fully human TNF- $\alpha$ monoclonal IgG1 antibody which blocks soluble and membrane-bound TNF- $\alpha$ from binding their natural receptors. ${ }^{80}$ It is currently 
FDA-approved for treating moderate to severe psoriasis, moderate to severe PsA, adult rheumatoid arthritis, juvenile rheumatoid arthritis in patients as young as 4 years old, ankylosing spondylitis, and Crohn's disease. ${ }^{27,46,50,66}$ For psoriasis, adalimumab is administered SC at a dose of $80 \mathrm{mg}$ the first week, followed by $40 \mathrm{mg}$ the next week and every other week (EOW) thereafter. For PsA, adalimumab is administered SC at $40 \mathrm{mg}$ EOW.

Clinical response to adalimumab is substantial and rapid, with statistically significant improvement in PASI occurring as early as 1 week after initiation of treatment. ${ }^{80,81}$ One meta-analysis reported that adalimumab has superior efficacy in treating moderate to severe psoriasis when compared to etanercept, efalizumab, alefacept, methotrexate, cyclosporine, acitretin, and fumaric acid esters. ${ }^{74}$ Rebound is uncommon upon discontinuation of adalimumab, but clinical response is better maintained with continuous than as-needed therapy. ${ }^{82}$ Sustained clinical response has been noted for as long as 60 weeks with continuous adalimumab treatment. ${ }^{80}$ A relatively small proportion of patients experience loss of adalimumab efficacy with continued use..$^{80,82}$ In one phase III active comparator trial, adalimumab demonstrated significantly higher efficacy and was better tolerated than methotrexate. $^{81}$

Similar to etanercept, the slow absorption rate following $\mathrm{SC}$ administration, slow elimination rate, and appropriate dosing frequency give adalimumab a smooth and uniform concentration-time profile, minimizing the occurrences of overexposure and resultant adverse events, as well as underexposure and consequent symptom recurrence. ${ }^{52,53}$

Like etanercept, adalimumab is administered via a fixed-dose regimen and does not take the patient's weight into account. In a recent study of 144 patients with psoriasis and PsA treated with adalimumab, PASI 50 response was achieved by significantly more patients with BMI less than $30(79 \%)$ than obese patients with BMI 30 or higher $(58 \%) .{ }^{83}$ This supports the notion that adalimumab may be less efficacious in treating heavier patients than normal-weight individuals.

Several clinical trials have reported the efficacy and safety of adalimumab in treating psoriasis and PsA (Table 2). There are, however, less data available for adalimumab than for etanercept and infliximab, since adalimumab is the newest of the three TNF- $\alpha$ inhibitors.

The most common AEs associated with adalimumab use are infection, injection site reaction, increased LFTs, and pruritus. There exist rare reports of anaphylaxis, angioedema, exacerbation of or new-onset CHF, cytopenia, fever, flushing, interstitial pneumonitis or fibrosis, leukocytoclastic vasculitis, lupus erythematosus syndrome, malignancy (eg, Hodgkin's lymphoma, CTCL, NMSC), menorrhagia, MS and other demyelinating disease, sepsis, and severe infection. ${ }^{50,66,68,69,80-82}$

Contraindications for adalimumab use include chronic, active, serious, and recurrent infection, active TB, latent TB in the absence of chemoprophylaxis, hepatitis B, MS and other demyelinating disease, first-degree relative with MS, NYHA class III or IV CHF, pregnancy or lactation, and hypersensitivity to adalimumab or its ingredients. During treatment with adalimumab, patients should avoid live and live-attenuated vaccines. Table 3 lists monitoring recommendations for all TNF- $\alpha$ inhibitors.

\section{Alefacept}

In January 2003, alefacept became the first biologic agent approved by the FDA for the treatment of moderate to severe plaque psoriasis in adults who are candidates for systemic or ultraviolet therapy. Alefacept is a fully human fusion protein which acts to prevent the interaction between lymphocyte function-associated antigen-3 (LFA-3) and CD2. This blocks the activation of $\mathrm{T}$ cells, thus modifying the inflammatory process. Additionally, alefacept's immunoglobulin G1 domain interacts with natural killer cells to induce apoptosis of T cells. Both actions preferentially target memory/effector T cells, which have a high level of CD2 expression. ${ }^{84}$

The marketed dosing regimen of alefacept for psoriasis is a 12 -week course of $15 \mathrm{mg}$ intramuscularly (IM) given once weekly. ${ }^{97}$ An additional 12 -week course may be given after 12 or more weeks off of treatment if the CD4+ lymphocyte count is within the normal range. Phase I studies showed alefacept to be well-tolerated when administered via 30-second IV bolus or 30-minute IV infusion as well as IM; ${ }^{85,86}$ however, pharmacokinetic studies favor IV bolus and IM administration. Phase III data (Table 2) confirm the efficacy of IV and IM alefacept for plaque-type psoriasis. ${ }^{87-90}$ In an attempt to achieve more rapid or complete response than the approved regimen (15 mg IM QW), Cafardi et al ${ }^{91}$ performed a small-scale comparison study of high-dose alefacept (30 mg IM QW for 12 weeks) versus loading dose followed by maintenance therapy (30 mg IM QW for 6 weeks + 15 mg IM QW for 6 weeks). There was no difference in efficacy between the groups, but there was a higher rate of adverse events in the group receiving higher doses of alefacept. Thus the dosing regimen remains $15 \mathrm{mg}$ IM QW for a 12-week course.

Efficacy data from clinical trials of alefacept via both IV and IM routes as treatment for chronic plaque psoriasis 
are summarized in Table 2. In general, up to one-third of patients achieve PASI 75 response during or after treatment with alefacept. Patients who achieve a physician's global assessment (PGA) score of "clear" or "almost clear" do not, in general, require further anti-psoriasis treatment for 10 months following a course of alefacept. ${ }^{85}$

Alefacept has been studied in but is not FDA-approved for PsA. In a phase II study, 185 patients received 12 weeks of methotrexate (MTX) plus either alefacept or placebo followed by 12 weeks of treatment with methotrexate alone. ${ }^{92}$ At week $24,54 \%$ of patients in the alefacept + MTX group and $23 \%$ in the placebo + MTX group achieved at least a $20 \%$ decrease in the American College of Rheumatology response criteria (ACR-20). Further studies are needed to confirm the efficacy of alefacept in the treatment of psoriatic arthritis.

Per data from phase II and III randomized controlled trials, patients receiving alefacept have significantly greater improvements in dermatology-related quality of life (QOL) measures than patients receiving placebo. ${ }^{93,94}$ This improvement is sustained up to twelve weeks after completion of the treatment course, and a second 12-week course provides additional QOL benefit. ${ }^{95}$ PASI 50 or greater response is associated with significantly greater improvement in QOL scores, and alefacept therapy does not negatively impact QOL.

AEs reported in patients treated with alefacept are generally mild. Adverse events reported with at least 5\% higher incidence with alefacept than placebo are chills, headache, pruritus, infection, rhinitis, injection site pain, injection site inflammation, and accidental injury (Table 2). The majority of infectious AEs reported with alefacept are due to the common cold.

Consistent with its mechanism of action, alefacept is known to cause a dose-dependent reduction in the total number of circulating lymphocytes as well as CD4+ and CD8+ memory $\mathrm{T}$ lymphocyte subsets. ${ }^{85}$ The reduction in CD4+ T lymphocyte (CD4) count correlates with disease activity. ${ }^{96}$ The vast majority of patients experience a return in $\mathrm{CD} 4$ count to within normal limits by 12 weeks following cessation of therapy. ${ }^{96}$ Current recommendations are to monitor CD4 count weekly throughout the treatment course, to withhold one dose for CD4 count less than 250 cells per microliter, and to discontinue therapy if $\mathrm{CD} 4$ count remains under 250 cells per microliter for 1 month. ${ }^{97}$ There have been no reports of opportunistic infection related or unrelated to $\mathrm{CD} 4$ count, increased risk of TB or viral reactivation, or increased incidence of malignancy, even with repeated courses of alefacept. ${ }^{98}$
The addition of localized use of topical corticosteroids provides no increased efficacy over alefacept alone and in fact is associated with further decrease in circulating memory T-cells over alefacept with vehicle. ${ }^{99}$ In another report, systemic anti-psoriasis therapy was added to alefacept in a small group of patients. ${ }^{100}$ Concomitant therapies used were methotrexate $(n=4)$, acitretin $(n=2)$, and cyclosporine $(n=1)$. Combination alefacept + systemic anti-psoriasis therapy led to slight increase in efficacy with no impact on CD4 count. Krueger et $\mathrm{al}^{89}$ report on an open-label study of 449 patients with plaque psoriasis treated with up to three 12-week courses of alefacept. Approximately one-third of patients were treated with alefacept alone or in combination with low-potency topical therapy, one-third were treated with alefacept plus medium- to high-potency topical therapy, and one-third were treated with alefacept plus a systemic or ultraviolet B (UVB) therapy. Because patients were permitted to receive different concomitant therapies between courses, the study was not powered to compare efficacy between therapies. Combination therapy did improve efficacy, however, particularly alefacept plus UVB. The improved efficacy of treatment with alefacept plus UVB over alefacept alone has been demonstrated in two other open-label clinical trials..$^{90,101}$

\section{Efalizumab}

Efalizumab is a monoclonal humanized form of a murine antibody directed against CD11a, the $\alpha$ subunit of lymphocyte function-associated antigen-1 (LFA-1). By binding to CD11a, efalizumab inhibits cutaneous T cell trafficking, ${ }^{102}$ $\mathrm{T}$ cell activation, and $\mathrm{T}$ cell adhesion to keratinocytes. ${ }^{103}$ In 2003 it was approved by the FDA for continuous treatment of moderate to severe plaque psoriasis for adults who are eligible for systemic therapy, and in 2004 it was approved by the European Medicines Agency for adults who have failed to respond to or are intolerant of other systemic therapies. The marketed regimen of efalizumab use was one initial dose of $0.7 \mathrm{mg} / \mathrm{kg}$ SC followed by weekly injections of $1 \mathrm{mg} / \mathrm{kg}$ $\mathrm{SC}$ to a maximum $200 \mathrm{mg}$. In April 2009, efalizumab was withdrawn from the market based on several reports of progressive multifocal leukoencephalopathy (PML) in patients being treated with efalizumab.

A phase III dose-finding trial demonstrated significantly superior efficacy of each of 3 doses of efalizumab (1, 2, and $4 \mathrm{mg} / \mathrm{kg} /$ week) to placebo and provided evidence supporting weekly dosing over EOW dosing. ${ }^{104}$ This and other studies showed that increasing the weekly SC dose from $1 \mathrm{mg} / \mathrm{kg}$ to $2 \mathrm{mg} / \mathrm{kg}$ did not achieve a higher rate of response. ${ }^{105}$ 
Data from several phase III studies support continuous use of efalizumab dosed at $1 \mathrm{mg} / \mathrm{kg} \mathrm{SC} \mathrm{QW} \mathrm{in} \mathrm{patients} \mathrm{with} \mathrm{good}$ initial clinical response. ${ }^{105-108}$ Efalizumab also demonstrated efficacy in treating palmoplantar psoriasis in several case reports and small open-label pilot studies. ${ }^{109-115}$ Treatment with efalizumab is also associated with significant improvement in dermatology-related quality of life and psoriasis symptoms severity measures. ${ }^{116}$ Efalizumab has been shown to be ineffective in the treatment of psoriatic arthritis. ${ }^{117}$

The incidence of AEs reported in clinical trials of efalizumab are reported in Table 2. The most frequent AEs are flu-like symptoms: headache, chills, nausea, and myalgias are reported more frequently in patients receiving efalizumab than those receiving placebo. These are typically mild and acute, and their incidence decreases with ongoing treatment. ${ }^{118}$ In large RCTs, the frequency of SAEs was not significantly different in patients treated with efalizumab compared with placebo (Table 2). There have been reports of both immune-mediated thrombocytopenia ${ }^{119}$ and autoimmune hemolytic anemia ${ }^{120}$ within the first 6 months of treatment with efalizumab for psoriasis. These events are rare but serious, and guidelines suggest monitoring complete blood counts in patients on efalizumab. ${ }^{66}$

Both worsening of psoriasis and new-onset arthritis have been reported during therapy with efalizumab. Pooled data from four placebo-controlled trials indicate that the incidence of psoriasis adverse events, including worsening disease and onset of new psoriasis morphologies was 3\% in patients treated with efalizumab and $1 \%$ in those treated with placebo. In a small retrospective analysis, ten patients with psoriasis-related AEs during long-term efalizumab treatment were treated with intercurrent cyclosporine. ${ }^{121}$ This combination therapy was generally well-tolerated and effectively controlled the relapse. No patient experienced a serious adverse event or psoriasis rebound or flare.

The FDA has received reports of three confirmed cases and one possible unconfirmed case of progressive multifocal leukoencephalopathy (PML), a life-threatening central nervous system infection in patients being treated with efalizumab for psoriasis. ${ }^{122}$ This initially led to a black box warning for PML and efalizumab, followed in April 2009 by efalizumab being withdrawn from the consumer market. All patients treated with efalizumab are expected to discontinue therapy by July 2009.

Psoriasis rebound or flare following abrupt withdrawal of efalizumab is well documented and must be considered when discontinuing efalizumab. This flare may be seen as soon as after missing a single dose of efalizumab. ${ }^{123}$
The post-efalizumab discontinuation flare may manifest as generalized erythrodermic or pustular psoriasis, ${ }^{124}$ guttate psoriasis, ${ }^{125}$ or recurrent plaque psoriasis. One study revealed efalizumab-responsive patients to be less likely to experience rebound than non-responders. ${ }^{126}$ Management of the postefalizumab flare should be approached on a case-by-case basis. One must consider comorbidities, prior and planned future treatment, and contraindications to other psoriasis therapies. Cyclosporine and methotrexate have been proven efficacious in many but not all ${ }^{127}$ reports. In an open-label study comparing post-efalizumab treatments, cyclosporine and methotrexate were superior to systemic corticosteroids, retinoids, or combined corticosteroids and methotrexate in preventing rebound. ${ }^{128}$ In one study of 130 patients, no patient who was placed on cyclosporine or methotrexate immediately on discontinuation of efalizumab experienced rebound. ${ }^{126}$ These findings suggest that when transitioning a patient from efalizumab to another biologic agent, one may consider bridging therapy with cyclosporine or methotrexate in an attempt to decrease the likelihood and/or severity of psoriasis rebound until the new agent has taken effect.

\section{Ustekinumab}

In recent years, biologic agents targeting IL-12/23 have shown great promise. ${ }^{129}$ Both agents target the p40 subunit shared by IL-12 and IL-23, which are over-expressed in psoriasis plaques. ${ }^{130}$ The so-called "anti-IL-12" drugs include ustekinumab (CNTO 1275) and ABT-874. Ustekinumab is currently in the final approval stages at the FDA, while ABT-874 is currently in early phase III studies.

Ustekinumab (formerly CNTO-1275) is a human monoclonal antibody that binds with high affinity and specificity to $\mathrm{p} 40$, thereby preventing interaction with cell-surface IL12R $\beta 1$ receptors. It has been proven efficacious in the treatment of Crohn's disease ${ }^{131}$ in addition to psoriasis and psoriatic arthritis. It has been unsuccessful in the treatment of MS. ${ }^{132}$ A phase I first-in-human study demonstrated concentration-dependent improvement of psoriasis lesions following a single IV dose of ustekinumab. ${ }^{133}$ Twelve of 18 subjects $(67 \%)$ achieved at least PASI 75 improvement between 8 and 16 weeks following administration. Dose-finding studies have determined that ustekinumab is efficacious in the treatment of psoriasis at 45 to $90 \mathrm{mg}$ SC every 8 to 12 weeks. The marketed dosing regimen is expected to be $45 \mathrm{mg}$ SC every 12 weeks.

Efficacy data from clinical trials of ustekinumab for moderate to severe chronic plaque psoriasis ${ }^{134}$ are summarized in Table 2. In the first comparator trial of two 
biologic agents, ustekinumab showed superiority compared with etanercept in the treatment of moderate to severe plaque psoriasis. ${ }^{135}$ In the study, ustekinumab $45 \mathrm{mg}$ or $90 \mathrm{mg} \mathrm{SC}$ at weeks 0 and 4 was compared with etanercept $50 \mathrm{mg} \mathrm{SC}$ twice weekly from weeks 0 to 12 . In the ustekinumab groups, $68 \%$ and $74 \%$ of participants (45 mg and $90 \mathrm{mg}$, respectively) achieved PASI 75 at week 12, compared with $57 \%$ of patients on etanercept.

In large phase III randomized controlled trials, participants treated with ustekinumab experienced greater decreases in dermatology life quality index (DLQI) scores than did placebotreated participants. At week 12 in a trial of 1230 patients, significantly more subjects treated with ustekinumab $45 \mathrm{mg}$ $(55 \%)$ and $90 \mathrm{mg}(56 \%)$ reached DLQI score of 0 or 1 than did those receiving placebo $(3 \%) .{ }^{136}$ Results were similar in another phase III study of 766 patients: DLQI of 0 or 1 was achieved by $53 \%$ of those treated with ustekinumab $45 \mathrm{mg}$, $52 \%$ treated with ustekinumab $90 \mathrm{mg}$, and $6 \%$ receiving placebo. ${ }^{137}$ The efficacy results of these two large phase III trials demonstrated that $67 \%$ of patients in both studies treated with $45 \mathrm{mg}$ of ustekinumab reached PASI 75 at week 12 and that $66 \%$ and $76 \%$ of patients treated with $90 \mathrm{mg}$ of ustekinumab reached PASI 75 at 12 weeks.

In a phase II double-blind, randomized, placebocontrolled crossover study of 146 adults, ustekinumab significantly reduced signs and symptoms of active psoriatic arthritis compared with placebo. ${ }^{138}$ Active psoriatic arthritis was defined as 3 or more swollen joints and 3 or more tender joints plus either C-reactive protein (CRP) of at least $15 \mathrm{mg} / \mathrm{L}$ or morning stiffness for at least 45 minutes. Patients were required to have been diagnosed with PsA at least 6 months prior to enrollment in the study. At week 12, 42\% of patients treated with ustekinumab (either $90 \mathrm{mg}$ or $63 \mathrm{mg}$ SC weekly at weeks $0-3$ ) and $14 \%$ of patients receiving placebo achieved ACR-20 response. Patients were also required to have active plaque psoriasis with a target lesion of at least $2 \mathrm{~cm}$ diameter, and ustekinumab also improved cutaneous lesions compared to placebo. Of the 124 (85\%) of patients with at least $3 \%$ or greater body surface area (BSA) involvement with psoriasis, $52 \%$ of ustekinumab-treated patients (33 of 63 ) and $5 \%$ of placebo-treated patients ( 3 of 55) achieved PASI 75 response at week 12 .

The incidence of adverse events in clinical trials of ustekinumab is summarized in Table 2. The most common AEs are upper respiratory tract infection, headache, nasopharyngitis, injection site erythema, and arthralgias. In trials conducted to date, there does not appear to be a significant difference in the incidence of serious adverse events, infectious adverse events, malignancy, cardiovascular events, or adverse events leading to treatment discontinuation. There has also been no dose-response in adverse event incidence or severity.

\section{ABT-874}

ABT-874 is a fully human antibody with high affinity for the shared p40 subunit of IL-12 and IL-23. This antibody displays very potent in vitro neutralization of IL-12, was very effective in animal models, and has demonstrated clinical efficacy in the treatment of psoriasis in human studies. ABT-874 is also being investigated for use in the treatment of Crohn's disease.

Phase II data reveal substantial and statistically significantly superior efficacy of ABT-874 at each of five different dosing regimens compared with placebo. ${ }^{139}$ This includes a single dose of ABT-874, after which $63 \%$ of patients demonstrated PASI 75 response 3 months later. These data are seen in Table 2. This effect is often sustained weeks to months following cessation of therapy.

Safety data thus far indicate that subjects treated with ABT-874 are not statistically significantly more likely than those treated with placebo to experience serious infectious, or malignant adverse events. Further safety and efficacy data are currently being obtained via numerous phase III studies.

\section{Summary}

When selecting a biologic agent for use in a patient with psoriasis, one must consider a number of characteristics both of the patient and of the medication. Patient-specific factors to consider include psoriasis morphology and severity, state of health, comorbidities, body mass index, concomitant therapy, and adherence. Medication-specific considerations include efficacy, adverse events and contraindications, method of administration, and physician experience with the agent. Unfortunately there is no simple way to determine which patient to treat with which agent. The choice of which agent to utilize is best made after obtaining a careful history and physical examination along with a detailed discussion with the patient about the advantages and disadvantages of all of the five currently available biologic therapies. Prior to initiating therapy with any biologic agent, appropriate screening studies include TB testing, complete blood count (CBC), hepatic function panel, hepatitis profile, and pregnancy testing as appropriate. Acceptable methods of TB screening include the purified protein derivative skin test and QuantiFERON Gold test (where available). 
Chest x-ray may also be utilized based on results of screening tests and in special circumstances as indicated by Centers of Disease Control and Prevention (CDC) guidelines. ${ }^{66,140}$ Re-testing for TB should be performed in all patients who are exposed to or demonstrate symptoms of TB, and annually in all patients being treated with biologic agents. Alefacept, adalimumab, etanercept, and infliximab are pregnancy category $\mathrm{B}$ medications, and efalizumab is a pregnancy category $\mathrm{C}$ medication.

Patients initiating treatment with alefacept must have a CD4 count done prior to initiating treatment and then biweekly during treatment. Alefacept dose should be held for CD4 count less than 250 cells per microliter. Alefacept is contraindicated in HIV-infected patients, and because new CDC guidelines recommend HIV testing in all patients who present for medical care, ${ }^{141}$ one may consider HIV testing in all patients being screened for any biologic agent.

Anti-TNF- $\alpha$ agents are contraindicated in the presence of serious infections such as TB, opportunistic infections, and hepatitis B. They should also not be used with live vaccines. Biologically inactive or recombinant vaccine use is acceptable in patients being treated with TNF- $\alpha$ antagonists, but the immune response of the vaccine may be compromised. Because of the association between TNF- $\alpha$ inhibitors and demyelinating disease, they should not be used in patients with these diseases. First-degree relatives of patients with MS have an increased risk of developing MS themselves; one should therefore avoid treatment with TNF- $\alpha$ inhibitors in first-degree relatives of patients with MS. Use of TNF- $\alpha$ inhibitors may lead to new-onset or exacerbation of CHF. Caution should therefore be exercised in patients with $\mathrm{CHF}$, particularly those with left ventricular ejection fraction less than $50 \%$. Use of TNF- $\alpha$ antagonists should be avoided in patients with NYHA Functional Class 3 or $4 \mathrm{CHF}$, and infliximab use at doses greater than $5 \mathrm{mg} / \mathrm{kg}$ is contraindicated in these patients. Etanercept is contraindicated in sepsis. Patients who are treated with TNF- $\alpha$ inhibitors should be alerted of common adverse events (such as the painful injection site reaction seen in some patients treated with adalimumab) as well as rare but serious adverse events such as drug-induced lupus, serum sickness, and malignancy (including hepatosplenic T-cell lymphoma in children treated with infliximab).

The biologic agents have greatly increased the treatment choices for patients with moderate to severe psoriasis as well as those with moderate to severe PsA. These newer agents not only offer new choices, but based upon the short- and intermediate-term data that are currently available, the biologic agents also appear to offer safer, more effective, and convenient therapies.

\section{Disclosures}

Dr. Korman has been a consultant for Abbott, Astellas, Centocor, and Genentech and been a speaker for Abbott, Amgen, Astellas, Centocor, and Genentech. Dr. Korman also receives residency/ fellowship funding from Centocor. Dr. Bahner has been a sub-investigator in clinical trials conducted by Abbott, Amgen, Astellas, Centocor, and Genentech.

\section{References}

1. Greaves MW, Weinstein GD. Treatment of psoriasis. $N$ Engl J Med. 1995;332(9):581-588.

2. Lowes MA, Bowcock AM, Krueger JG. Pathogenesis and therapy of psoriasis. Nature. 2007;445(7130):866-873.

3. Jobling RG. Psoriasis: a preliminary questionnaire study of sufferers' subjective experience. Clin Exp Dermatol. 1976;1(3):233-236.

4. Koo J. Population-based epidemiologic study of psoriasis with emphasis on quality of life assessment. Dermatol Clin. 1996;14(3):485-496.

5. Fried RG, Friedman S, Paradis C, et al. Trivial or terrible? The psychosocial impact of psoriasis. Int J Dermatol. 1995;34(2):101-105.

6. Gupta MA, Gupta AK. Quality of life of psoriasis patients. J Eur Acad Dermatol Venereol. 2000;14(4):241-242.

7. Devrimci-Ozguven H, Kundakci TN, Kumbasar H, Boyvat A. The depression, anxiety, life satisfaction and affective expression levels in psoriasis patients. J Eur Acad Dermatol Venereol. 2000;14(4):267-271.

8. Wahl A, Loge JH, Wiklund I, Hanestad BR. The burden of psoriasis: a study concerning health-related quality of life among Norwegian adult patients with psoriasis compared with general population norms. J Am Acad Dermatol. 2000;43(5 pt 1):803-808.

9. Langley RG, Krueger GG, Griffiths CE. Psoriasis: epidemiology, clinical features, and quality of life. Ann Rheum Dis. 2005;64(Suppl 2): ii18-23.

10. Feldman SR, Fleischer AB Jr, Reboussin DM, et al. The economic impact of psoriasis increases with psoriasis severity. $J$ Am Acad Dermatol. 1997;37(4):564-569.

11. Chaudhari U, Romano P, Mulcahy LD, Dooley LT, Baker DG, Gottlieb AB. Efficacy and safety of infliximab monotherapy for plaque-type psoriasis: a randomised trial. Lancet. 2001;357(9271): 1842-1847.

12. Stern RS, Nijsten T, Feldman SR, Margolis DJ, Rolstad T. Psoriasis is common, carries a substantial burden even when not extensive, and is associated with widespread treatment dissatisfaction. J Investig Dermatol Symp Proc. 2004;9(2):136-139.

13. Hamminga EA, van der Lely AJ, Neumann HA, Thio HB. Chronic inflammation in psoriasis and obesity: implications for therapy. Med Hypotheses. 2006;67(4):768-773.

14. Neimann AL, Shin DB,Wang X, Margolis DJ, Troxel AB, Gelfand JM. Prevalence of cardiovascular risk factors in patients with psoriasis. J Am Acad Dermatol. 2006;55(5):829-835.

15. Sommer DM, Jenisch S, Suchan M, Christophers E, Weichenthal M. Increased prevalence of the metabolic syndrome in patients with moderate to severe psoriasis. Arch Dermatol Res. 2006;298(7):321-328.

16. Lebwohl M. Psoriasis. Lancet. 2003;361(9364):1197-1204.

17. Wong K, Gladman DD, Husted J, Long JA, Farewell VT. Mortality studies in psoriatic arthritis: results from a single outpatient clinic. I. Causes and risk of death. Arthritis Rheum. 1997;40(10):1868-1872.

18. Gladman DD, Farewell VT, Wong K, Husted J. Mortality studies in psoriatic arthritis: results from a single outpatient center. II. Prognostic indicators for death. Arthritis Rheum. 1998;41(6):1103-1110. 
19. Krueger JG. The immunologic basis for the treatment of psoriasis with new biologic agents. J Am Acad Dermatol. 2002;46(1):1-23.

20. Willkens RF, Williams HJ, Ward JR, et al. Randomized, double-blind, placebo controlled trial of low-dose pulse methotrexate in psoriatic arthritis. Arthritis Rheum. 1984;27(4):376-381.

21. Clegg DO, Reda DJ, Mejias E, et al. Comparison of sulfasalazine and placebo in the treatment of psoriatic arthritis. A Department of Veterans Affairs Cooperative Study. Arthritis Rheum. 1996;39(12):2013-2020.

22. Salvarani C, Macchioni P, Olivieri I, et al. A comparison of cyclosporine, sulfasalazine, and symptomatic therapy in the treatment of psoriatic arthritis. J Rheumatol. 2001;28(10):2274-2282.

23. Pipitone N, Kingsley GH, Manzo A, Scott DL, Pitzalis C. Current concepts and new developments in the treatment of psoriatic arthritis. Rheumatology (Oxford). 2003;42(10):1138-1148.

24. Jones G, Crotty M, Brooks P. Interventions for psoriatic arthritis. Cochrane Database Syst Rev. 2000;(3):CD000212.

25. Kaltwasser JP, Nash P, Gladman D, et al. Efficacy and safety of leflunomide in the treatment of psoriatic arthritis and psoriasis: a multinational, double-blind, randomized, placebo-controlled clinical trial. Arthritis Rheum. 2004;50(6):1939-1950.

26. Saini R, Tutrone WD, Weinberg JM. Advances in therapy for psoriasis: an overview of infliximab, etanercept, efalizumab, alefacept, adalimumab, tazarotene, and pimecrolimus. Curr Pharm Des. 2005 11(2):273-280.

27. Schottelius AJ, Moldawer LL, Dinarello CA, Asadullah K, Sterry W, Edwards CK 3rd. Biology of tumor necrosis factor-alpha- implications for psoriasis. Exp Dermatol. 2004;13(4):193-222.

28. Kristensen M, Chu CQ, Eedy DJ, Feldmann M, Brennan FM, Breathnach SM. Localization of tumour necrosis factor-alpha (TNF-alpha) and its receptors in normal and psoriatic skin: epidermal cells express the 55-kD but not the $75-\mathrm{kD}$ TNF receptor. Clin Exp Immunol. 1993;94(2):354-362.

29. Nickoloff BJ, Karabin GD, Barker JN, et al. Cellular localization of interleukin-8 and its inducer, tumor necrosis factor-alpha in psoriasis. Am J Pathol. 1991;138(1):129-140.

30. Uyemura K, Yamamura M, Fivenson DF, Modlin RL, Nickoloff BJ. The cytokine network in lesional and lesion-free psoriatic skin is characterized by a T-helper type 1 cell-mediated response. $J$ Invest Dermatol. 1993;101(5):701-705.

31. Bonifati C, Carducci M, Cordiali Fei P, et al. Correlated increases of tumour necrosis factor-alpha, interleukin-6 and granulocyte monocytecolony stimulating factor levels in suction blister fluids and sera of psoriatic patients - relationships with disease severity. Clin Exp Dermatol. 1994;19(5):383-387.

32. Ettehadi P, Greaves MW, Wallach D, Aderka D, Camp RD. Elevated tumour necrosis factor-alpha (TNF-alpha) biological activity in psoriatic skin lesions. Clin Exp Immunol. 1994;96(1):146-151.

33. Mussi A, Bonifati C, Carducci M, et al. Serum TNF-alpha levels correlate with disease severity and are reduced by effective therapy in plaque-type psoriasis. J Biol Regul Homeost Agents. 1997;11(3):115-118.

34. Arican O, Aral M, Sasmaz S, Ciragil P. Serum levels of TNF-alpha, IFN-gamma, IL-6, IL-8, IL-12, IL-17, and IL-18 in patients with active psoriasis and correlation with disease severity. Mediators Inflamm. 2005;2005(5):273-279.

35. Partsch G, Steiner G, Leeb BF, Dunky A, Bröll H, Smolen JS. Highly increased levels of tumor necrosis factor-alpha and other proinflammatory cytokines in psoriatic arthritis synovial fluid. $J$ Rheumatol. 1997;24(3):518-523.

36. Ritchlin C, Haas-Smith SA, Hicks D, Cappuccio J, Osterland CK, Looney RJ. Patterns of cytokine production in psoriatic synovium. J Rheumatol. 1998;25(8):1544-1552.

37. Danning CL, Illei GG, Hitchon C, Greer MR, Boumpas DT, McInnes IB. Macrophage-derived cytokine and nuclear factor kappaB p 65 expression in synovial membrane and skin of patients with psoriatic arthritis Arthritis Rheum. 2000;43(6):1244-1256.
38. Ameglio F, Bonifati C, Pietravalle M, Fazio M. Interleukin-6 and tumour necrosis factor levels decrease in the suction blister fluids of psoriatic patients during effective therapy. Dermatology. 1994;189(4): 359-363.

39. Olaniran AK, Baker BS, Paige DG, Garioch JJ, Powles AV, Fry L. Cytokine expression in psoriatic skin lesions during PUVA therapy. Arch Dermatol Res. 1996;288(8):421-425.

40. Mease PJ, Goffe BS, Metz J, VanderStoep A, Finck B, Burge DJ. Etanercept in the treatment of psoriatic arthritis and psoriasis: a randomised trial. Lancet. 2000;356(9227):385-390.

41. Gottlieb AB, Matheson RT, Lowe N, et al. A randomized trial of etanercept as monotherapy for psoriasis. Arch Dermatol. 2003;139(12):1627-1632.

42. Leonardi CL, Powers JL, Matheson RT, et al. Etanercept as monotherapy in patients with psoriasis. $N$ Engl J Med. 2003;349(21):2014-2022.

43. Elewski B, Leonardi C, Gottlieb AB, et al. Comparison of clinical and pharmacokinetic profiles of etanercept $25 \mathrm{mg}$ twice weekly and $50 \mathrm{mg}$ once weekly in patients with psoriasis. Br J Dermatol. 2007;156(1): $138-142$.

44. Nestorov I, Zitnik R, Ludden T. Population pharmacokinetic modeling of subcutaneously administered etanercept in patients with psoriasis. J Pharmacokinet Pharmacodyn. 2004;31(6):463-490.

45. Papp KA, Tyring S, Lahfa M, et al. A global phase III randomized controlled trial of etanercept in psoriasis: safety, efficacy, and effect of dose reduction. Br J Dermatol. 2005;152(6):1304-1312.

46. Pietrzak AT, Zalewska A, Chodorowska G, et al. Cytokines and anticytokines in psoriasis. Clin Chim Acta. 2008;394(1-2):7-21.

47. Tyring S, Gordon KB, Poulin Y, et al. Long-term safety and efficacy of $50 \mathrm{mg}$ of etanercept twice weekly in patients with psoriasis. Arch Dermatol. 2007;143(6):719-726.

48. Moore A, Gordon KB, Kang S, et al. A randomized, open-label trial of continuous versus interrupted etanercept therapy in the treatment of psoriasis. J Am Acad Dermatol. 2007;56(4):598-603.

49. Gordon K, Korman N, Frankel E, et al. Efficacy of etanercept in an integrated multistudy database of patients with psoriasis. $\mathrm{J} \mathrm{Am} \mathrm{Acad}$ Dermatol. 2006;54(3 Suppl 2):S101-S111.

50. Mössner R, Schön MP, Reich K. Tumor necrosis factor antagonists in the therapy of psoriasis. Clin Dermatol. 2008;26(5):486-502.

51. Weinberg JM. An overview of infliximab, etanercept, efalizumab, and alefacept as biologic therapy for psoriasis. Clin Ther. 2003;25(10): $2487-2505$.

52. Nestorov I. Clinical pharmacokinetics of TNF antagonists: how do they differ? Semin Arthritis Rheum. 2005;34(5 Suppl1):12-18.

53. Nestorov I. Clinical pharmacokinetics of tumor necrosis factor antagonists. J Rheumatol Suppl. 2005;74:13-18.

54. Centers for Disease Control and Prevention. Health, United States, 2005. Hyattsville, MD. Available from: http://www.cdc.gov/nchs/data/hus/ hus05.pdf\#summary.

55. Naldi L, Chatenoud L, Linder D, et al. Cigarette smoking, body mass index, and stressful life events as risk factors for psoriasis: results from an Italian case-control study. $J$ Invest Dermatol. 2005;125(1):61-67.

56. McGowan JW, Pearce DJ, Chen J, Richmond D, Balkrishnan R, Feldman SR. The skinny on psoriasis and obesity. Arch Dermatol. 2005;141(12):1601-1602.

57. Herron MD, Hinckley M, Hoffman MS, et al. Impact of obesity and smoking on psoriasis presentation and management. Arch Dermatol. 2005;141(12):1527-1534.

58. Sterry W, Strober BE, Menter A; International Psoriasis Council. Obesity in psoriasis: the metabolic, clinical and therapeutic implications Report of an interdisciplinary conference and review. Br J Dermatol. 2007;157(4):649-655.

59. Roenigk HH Jr, Auerbach R, Maibach H, Weinstein G, Lebwohl M. Methotrexate in psoriasis: consensus conference. $\mathrm{J} \mathrm{Am} \mathrm{Acad} \mathrm{Dermatol.}$ 1998;38(3):478-485.

60. Strober B, Gottlieb A, Leonardi C, Papp K. Levels of response of psoriasis patients with different baseline characteristics treated with etanercept. J Am Acad Dermatol. 2006;54(3 Suppl):AB220. 
61. Tyring S, Gottlieb A, Papp K, et al. Etanercept and clinical outcomes, fatigue, and depression in psoriasis: double-blind placebo-controlled randomised phase III trial. Lancet. 2006;367(9504):29-35.

62. Saraceno R, Schipani C, Mazzotta A, et al. Effect of anti-tumor necrosis factor-alpha therapies on body mass index in patients with psoriasis. Pharmacol Res. 2008;57(4):290-295.

63. Feldman SR, Kimball AB, Krueger GG, Woolley JM, Lalla D, Jahreis A. Etanercept improves the health-related quality of life of patients with psoriasis: results of a phase III randomized clinical trial. $J$ Am Acad Dermatol. 2005;53(5):887-889.

64. Krueger GG, Langley RG, Finlay AY, et al. Patient-reported outcomes of psoriasis improvement with etanercept therapy: results of a randomized phase III trial. Br J Dermatol. 2005;153(6):1192-1199.

65. Paller AS, Siegfried EC, Langley RG, et al. Etanercept treatment for children and adolescents with plaque psoriasis. $N$ Engl J Med. 2008;358(3):241-251

66. Menter A, Gottlieb A, Feldman SR, et al. Guidelines of care for the management of psoriasis and psoriatic arthritis: Section 1. Overview of psoriasis and guidelines of care for the treatment of psoriasis with biologics. J Am Acad Dermatol. 2008;58(5):826-850.

67. Gottlieb AB, Leonardi CL, Goffe BS, et al. Etanercept monotherapy in patients with psoriasis: a summary of safety, based on an integrated multistudy database. J Am Acad Dermatol. 2006;54(3 Suppl 2): S $92-$ S 100 .

68. Desai SB, Furst DE. Problems encountered during anti-tumour necrosis factor therapy. Best Pract Res Clin Rheumatol. 2006;20(4):757-790.

69. Brimhall AK, King LN, Licciardone JC, Jacobe H, Menter A. Safety and efficacy of alefacept, efalizumab, etanercept and infliximab in treating moderate to severe plaque psoriasis: a meta-analysis of randomized controlled trials. Br J Dermatol. 2008;159(2):274-285.

70. Knight DM, Trinh H, Le J, et al. Construction and initial characterization of a mouse-human chimeric anti-TNF antibody. Mol Immunol. 1993;30(16):1443-1453.

71. Gottlieb AB, Masud S, Ramamurthi R, et al. Pharmacodynamic and pharmacokinetic response to anti-tumor necrosis factor-alpha monoclonal antibody (infliximab) treatment of moderate to severe psoriasis vulgaris. $J$ Am Acad Dermatol. 2003;48(1):68-75.

72. Gottlieb AB, Evans R, Li S, et al. Infliximab induction therapy for patients with severe plaque-type psoriasis: a randomized, double-blind, placebo-controlled trial. J Am Acad Dermatol. 2004;51(4):534-542.

73. Menter A, Feldman SR, Weinstein GD, et al. A randomized comparison of continuous vs intermittent infliximab maintenance regimens over 1 year in the treatment of moderate-to-severe plaque psoriasis. $J$ Am Acad Dermatol. 2007;56(1):31.e1-e15.

74. Schmitt J, Zhang Z, Wozel G, Meurer M, Kirch W. Efficacy and tolerability of biologic and nonbiologic systemic treatments for moderate-to-severe psoriasis: meta-analysis of randomized controlled trials. Br J Dermatol. 2008;159(3):513-526.

75. Reich K, Nestle FO, Papp K, et al. Infliximab induction and maintenance therapy for moderate-to-severe psoriasis: a phase III, multicentre, double-blind trial. Lancet. 2005;366(9494):1367-1374.

76. Bendtzen K, Geborek P, Svenson M, Larsson L, Kapetanovic MC, Saxne T. Individualized monitoring of drug bioavailability and immunogenicity in rheumatoid arthritis patients treated with the tumor necrosis factor alpha inhibitor infliximab. Arthritis Rheum. 2006;54(12):3782-3789.

77. Knight DM, Trinh H, Le J, et al. Construction and initial characterization of a mouse-human chimeric anti-TNF antibody. Mol Immunol. 1993; 30(16):1443-1453.

78. Scallon B, Cai A, Solowski N, et al. Binding and functional comparisons of two types of tumor necrosis factor antagonists. J Pharmacol Exp Ther. 2002;301(2):418-426.

79. Reich K, Gottlieb AB, Kimball A, Li S. Consistency of infliximab response across subgroups of patients with psoriasis: integrated results from randomized controlled clinical trials. J Am Acad Dermatol. 2006;54(3 Suppl):AB215.
80. Gordon KB, Langley RG, Leonardi C, et al. Clinical response to adalimumab treatment in patients with moderate to severe psoriasis: double-blind, randomized controlled trial and open-label extension study. J Am Acad Dermatol. 2006;55(4):598-606.

81. Saurat JH, Stingl G, Dubertret L, et al. Efficacy and safety results from the randomized controlled comparative study of adalimumab vs methotrexate vs placebo in patients with psoriasis (CHAMPION). Br J Dermatol. 2008;158(3):558-566.

82. Menter A, Tyring SK, Gordon K, et al. Adalimumab therapy for moderate to severe psoriasis: A randomized, controlled phase III trial. J Am Acad Dermatol. 2008;58(1):106-115.

83. Cassano N, Galluccio A, De Simone C, et al. Influence of body mass index, comorbidities and prior systemic therapies on the response of psoriasis to adalimumab: an exploratory analysis from the APHRODITE data. J Biol Regul Homeost Agents. 2008;22(4):233-237.

84. Sugiyama H, McCormick TS, Cooper KD, Korman NJ. Alefacept in the treatment of psoriasis. Clin Dermatol. 2008;26(5):503-508.

85. Ellis CN, Krueger GG; Alefacept Clinical Study Group. Treatment of chronic plaque psoriasis by selective targeting of memory effector T lymphocytes. N Engl J Med. 2001;345(4):248-255.

86. Rogge M, Ellis C, Krueger G, et al. Pharmacokinetics of LFA3TIP (Amevive) in chronic plaque psoriasis patients during repeated once-weekly intravenous administration. J Invest Dermatol. 1999;112(4):AB516.

87. Krueger GG, Papp KA, Stough DB, et al. A randomized, double-blind, placebo-controlled phase III study evaluating efficacy and tolerability of 2 courses of alefacept in patients with chronic plaque psoriasis. $J$ Am Acad Dermatol. 2002;47(6):821-833.

88. Lebwohl M, Christophers E, Langley R, et al. An international, randomized, double-blind, placebo-controlled phase 3 trial of intramuscular alefacept in patients with chronic plaque psoriasis. Arch Dermatol. 2003;139(6):719-727.

89. Krueger GG, Gottlieb AB, Sterry W, Korman N, Van De Kerkhof P. A multicenter, open-label study of repeat courses of intramuscular alefacept in combination with other psoriasis therapies in patients with chronic plaque psoriasis. J Dermatolog Treat. 2008;19(3):146-155.

90. Ortonne JP, Khemis A, Koo JY, Choi J. An open-label study of alefacept plus ultraviolet $\mathrm{B}$ light as combination therapy for chronic plaque psoriasis. J Eur Acad Dermatol Venereol. 2005;19(5):556-563.

91. Cafardi JA, Cantrell W, Wang W, Elmets CA, Elewski BE. The safety and efficacy of high-dose alefacept compared with a loading dose of alefacept in patients with chronic plaque psoriasis. Skinmed. 2008;7(2):67-72.

92. Mease PJ, Gladman DD, Keystone EC; Alefacept in Psoriatic Arthritis Study Group. Alefacept in combination with methotrexate for the treatment of psoriatic arthritis: results of a randomized, double-blind, placebo-controlled study. Arthritis Rheum. 2006;54(5):1638-1645.

93. Finlay AY, Salek MS, Haney J; Alefacept Clinical Study Group. Intramuscular alefacept improves health-related quality of life in patients with chronic plaque psoriasis. Dermatology. 2003;206(4): 307-315.

94. Ellis CN, Mordin MM, Adler EY. Effects of alefacept on health-related quality of life in patients with psoriasis: results from a randomized, placebo-controlled phase II trial. Am J Clin Dermatol. 2003;4(2): 131-139.

95. Feldman SR, Menter A, Koo JY. Improved health-related quality of life following a randomized controlled trial of alefacept treatment in patients with chronic plaque psoriasis. Br J Dermatol. 2004;150(2):317-326.

96. Gordon KB, Vaishnaw AK, O’Gorman J, Haney J, Menter A; Alefacept Clinical Study Group. Treatment of psoriasis with alefacept: correlation of clinical improvement with reductions of memory T-cell counts. Arch Dermatol. 2003;139(12):1563-1570.

97. Alefacept package insert. http://www.fda.gov/cder/foi/label/2003/ alefbio013003LB.pdf.

98. Lowe NJ, Gonzalez J, Bagel J, Caro I, Ellis CN, Menter A. Repeat courses of intravenous alefacept in patients with chronic plaque psoriasis provide consistent safety and efficacy. Int J Dermatol. 2003;42(3):224-230. 
99. Langewouters AM, Bovenschen HJ, De Jong EM, Van Erp PE, Van De Kerkhof PC. The effect of topical corticosteroids in combination with alefacept on circulating T-cell subsets in psoriasis. J Dermatolog Treat. 2007;18(5):279-285.

100. Langewouters AM, Van Erp PE, De Jong EM, Van De Kerkhof PC. The added therapeutic efficacy and safety of alefacept in combination with other (systemic) anti-psoriatics in refractory psoriasis. J Dermatolog Treat. 2006;17(6):362-369.

101. Legat FJ, Hofer A, Wackernagel A, et al. Narrowband UV-B phototherapy, alefacept, and clearance of psoriasis. Arch Dermatol. 2007;143(8):1016-1022.

102. Krueger J, Gottlieb A, Miller B, Dedrick R, Garovoy M, Walicke P. Anti-CD11a treatment for psoriasis concurrently increases circulating T-cells and decreases plaque T-cells, consistent with inhibition of cutaneous T-cell trafficking. J Invest Dermatol. 2000;115(2):333.

103. Werther WA, Gonzalez TN, O’Connor SJ, et al. Humanization of an anti-lymphocyte function-associated antigen (LFA)-1 monoclonal antibody and reengineering of the humanized antibody for binding to rhesus LFA-1. J Immunol. 1996;157(11):4986-4995.

104. Lebwohl M, Tyring SK, Hamilton TK, et al. A novel targeted T-cell modulator, efalizumab, for plaque psoriasis. $N$ Engl $\mathrm{J} \mathrm{Med}$. 2003;349(21):2004-2013.

105. Leonardi CL, Papp KA, ax KB, et al. Extended efalizumab therapy improves chronic plaque psoriasis: results from a randomized phase III trial. J Am Acad Dermatol. 2005;52(3 Pt 1):425-433.

106. Gordon KB, Papp KA, Hamilton TK, et al. Efalizumab for patients with moderate to severe plaque psoriasis: a randomized controlled trial. JAMA. 2003;290(23):3073-3080.

107. Menter A, Gordon K, Carey W, et al. Efficacy and safety observed during 24 weeks of efalizumab therapy in patients with moderate to severe plaque psoriasis. Arch Dermatol. 2005;141(1):31-38.

108. Gottlieb AB, Gordon KB, Lebwohl MG, et al. Extended efalizumab therapy sustains efficacy without increasing toxicity in patients with moderate to severe chronic plaque psoriasis. J Drugs Dermatol. 2004;3(6):614-624.

109. Fretzin S, Crowley J, Jones L, Young M, Sobell J. Successful treatment of hand and foot psoriasis with efalizumab therapy. J Drugs Dermatol. 2006;5(9):838-846.

110. Stinco G, Piccirillo F, Patrone P. Treatment of palmoplantar pustular psoriasis with efalizumab: a quick response with early recurrence. Eur J Dermatol. 2008;18(1):91-92.

111. Wozel G, Vitez L. Palmoplantar pustular psoriasis: successful therapy with efalizumab after non-response to infliximab. Acta Derm Venereol. 2008;88(2):169-170.

112. Colsman A, Carrascosa JM, Ferrandiz C, Simon JC. Successful treatment of recalcitrant palmoplantar psoriasis with efalizumab. J Eur Acad Dermatol Venereol. 2008;22(9):1131-1134.

113. Cohen DJ, Scherschun L. Case reports: practical experience with efalizumab in hand and foot psoriasis. J Drugs Dermatol. 2007;6(12) 1224-1230.

114. Varma R, Cafardi JA, Cantrell W, Elmets C. Safety and efficacy of subcutaneously administered efalizumab in adults with moderateto-severe hand and foot psoriasis: an open-label study. Am J Clin Dermatol. 2008;9(2):105-109.

115. Brunasso AM, Salvini C, Massone C. Efalizumab for severe palmoplantar psoriasis: an open-label pilot trial in five patients. J Eur Acad Dermatol Venereol. 2009;23(4):415-419.

116. Menter A, Kosinski M, Bresnahan BW, Papp KA, Ware JE Jr. Impact of efalizumab on psoriasis-specific patient-reported outcomes. Results from three randomized, placebo-controlled clinical trials of moderate to severe plaque psoriasis. J Drugs Dermatol. 2004;3(1):27-38.

117. Papp KA, Caro I, Leung HM, Garovoy M, Mease PJ. Efalizumab for the treatment of psoriatic arthritis. J Cutan Med Surg. 2007;11(2): 57-66.

118. Papp KA, Camisa C, Stone SP, et al. Safety of efalizumab in patients with moderate to severe chronic plaque psoriasis: review of clinical data. Part II. J Cutan Med Surg. 2005;9(6):313-323.
119. Warkentin TE, Kwon P. Immune thrombocytopenia associated with efalizumab therapy for psoriasis. Ann Intern Med. 2005;143(10):761-762.

120. Scheinfeld N. Efalizumab: a review of events reported during clinical trials and side effects. Expert Opin Drug Safety. 2006;5(2):197-209.

121. Costanzo A, Talamonti M, Spallone G, et al. Efficacy of short-term cyclosporine treatment to control psoriasis-related events during efalizumab therapy. Dermatology. 2009;218(2):146-150.

122. FDA Public Health Advisory: Updated Safety Information about Raptiva (efalizumab) http://www.fda.gov/cder/drug/advisory/efalizumab.htm

123. Lowes MA, Turton JA, Krueger JG, Barnetson RS. Psoriasis vulgaris flare during efalizumab therapy does not preclude future use: a case series. BMC Dermatol. 2005;5:9.

124. Gaylor ML, Duvic M. Generalized pustular psoriasis following withdrawal of efalizumab. J Drugs Dermatol. 2004;3(1):77-79.

125. Balato A, La Bella S, Gaudiello F, Balato N. Efalizumab-induced guttate psoriasis. Successful management and re-treatment. J Dermatolog Treat. 2008;19(3):182-184.

126. Menter A, Hamilton TK, Toth DP, et al. Transitioning patients from efalizumab to alternative psoriasis therapies: findings from an openlabel, multicenter, Phase IIIb study. Int J Dermatol. 2007;46(6): 637-648.

127. Maskatia ZK, Koo J. Rebound of psoriasis after efalizumab discontinuation, despite being on high-dose cyclosporine. J Drugs Dermatol. 2007;6(9):941-944.

128. Papp KA, Toth D, Rosoph L. Approaches to discontinuing efalizumab: an open-label study of therapies for managing inflammatory recurrence. BMC Dermatol. 2006;6:9.

129. Torti DC, Feldman SR. Interleukin-12, interleukin-23, and psoriasis: current prospects. J Am Acad Dermatol. 2007;57(6):1059-1068.

130. Yawalkar N, Karlen S, Hunger R, Brand CU, Braathen LR. Expression of interleukin-12 is increased in psoriatic skin. J Invest Dermatol. 1998;111(6):1053-1057.

131. Sandborn WJ, Feagan BG, Fedorak RN, et al. A randomized trial of ustekinumab, a human interleukin-12/23 monoclonal antibody, in patients with moderate-to-severe Crohn's disease. Gastroenterology. 2008;135(4):1130-1141.

132. Segal BM, Constantinescu CS, Raychaudhuri A, et al. Repeated subcutaneous injections of IL12/23 p40 neutralising antibody, ustekinumab, in patients with relapsing-remitting multiple sclerosis: a phase II, double-blind, placebo-controlled, randomised, dose-ranging study. Lancet Neurol. 2008;7(9):796-804.

133. Kauffman CL, Aria N, Toichi E, et al. A phase I study evaluating the safety, pharmacokinetics, and clinical response of a human IL-12 p40 antibody in subjects with plaque psoriasis. J Invest Dermatol. 2004;123(6):1037-1044.

134. Krueger GG, Langley RG, Leonardi C, et al. A human interleukin$12 / 23$ monoclonal antibody for the treatment of psoriasis. $N \mathrm{Engl}$ J Med. 2007;356(6):580-592.

135. [No authors listed] Trial watch: novel biologic for psoriasis shows superiority over current best-seller. Nat Rev Drug Discov. 2008;7(11):880-881.

136. Papp KA, Langley RG, Lebwohl M, et al. Efficacy and safety of ustekinumab, a human interleukin-12/23 monoclonal antibody, in patients with psoriasis: 52-week results from a randomised, double-blind, placebo-controlled trial (PHOENIX 2). Lancet. 2008;371(9625):1675-1684.

137. Leonardi CL, Kimball AB, Papp KA, et al. Efficacy and safety of ustekinumab, a human interleukin-12/23 monoclonal antibody, in patients with psoriasis: 76-week results from a randomised, double-blind, placebo-controlled trial (PHOENIX 1). Lancet. 2008;371(9625):1665-1674.

138. Gottlieb A, Menter A, Mendelsohn A, et al. Ustekinumab, a human interleukin 12/23 monoclonal antibody, for psoriatic arthritis: randomised, double-blind, placebo-controlled, crossover trial. Lancet. 2009;373(9664):633-640. 
139. Kimball AB, Gordon KB, Langley RG, et al. Safety and efficacy of ABT-874, a fully human interleukin 12/23 monoclonal antibody, in the treatment of moderate to severe chronic plaque psoriasis: results of a randomized, placebo-controlled, phase 2 trial. Arch Dermatol. 2008;144(2):200-207.

140. [No authors listed] Targeted tuberculin testing and treatment of latent tuberculosis infection. American Thoracic Society. MMWR Recomm Rep. 2000;49(RR-6):1-51

141. Branson BM, Handsfield HH, Lampe MA, et al; Centers for Disease Control and Prevention (CDC). Revised recommendations for HIV testing of adults, adolescents, and pregnant women in health-care settings. MMWR Recomm Rep. 2006;55(RR-14):1-17.
142. Papp KA, Bressinck R, Fretzin S, et al. Safety of efalizumab in adults with chronic moderate to severe plaque psoriasis: a phase IIIb, randomized, controlled trial. Int J Dermatol. 2006;45(5):605-614.

143. Dubertret L, Sterry W, Bos JD, et al. CLinical experience acquired with the efalizumab (Raptiva) (CLEAR) trial in patients with moderateto-severe plaque psoriasis: results from a phase III international randomized, placebo-controlled trial. $\mathrm{Br} J$ Dermatol. 2006; 155(1):170-181.

\section{Publish your work in this journal}

Clinical, Cosmetic and Investigational Dermatology is an international, peer-reviewed, open access, online journal that focuses on the latest clinical and experimental research in all aspects of skin disease and cosmetic interventions. All areas of dermatology will be covered; contributions will be welcomed from all clinicians and basic science researchers globally. This journal is indexed on CAS The manuscript management system is completely online and includes a very quick and fair peer-review system, which is all easy to use. Visit http://www.dovepress.com/testimonials.php to read real quotes from published authors.

Submit your manuscript here: http://www.dovepress.com/clinical-cosmetic-and-investigational-dermatology-journal 